\title{
Preparation and Reactions of 1,1-Zinc, Boron and 1,1-Copper, Boron Alkenyl Bimetallics
}

Jack R. Waas, AchyuthaRao Sidduri and Paul Knochel*

Willard H. Dow Laboratories, Department of Chemistry, University of Michigan

Ann Arbor, Michigan 48109

Key Words: Zinc, Boron Bimetallics, $d^{1}$-Reagents, Functionalized alkenyl coppers, Functionalized boronic esters

Summary: Pinacol $\alpha$-iodoalkenylboronates 8, readily prepared by the hydroboration of 1-iodoalkynes, were converted to 1,1-bimetallics of boron and zinc or copper which react with a wide range of electrophiles affording polyfunctional boronic esters. After $\mathrm{H}_{2} \mathrm{O}_{2}$ oxidation (30\% $\mathrm{H}_{2} \mathrm{O}_{2}$, sat. aq. $\mathrm{NaOAC}$, polyfunctional ketones were produced in good to excellent yields.

$\alpha$-Haloalkylboronic esters 1 represent a very useful class of boron intermediates for organic synthesis. ${ }^{1}$ Whereas $\alpha$ haloalkenylboronic esters 2 have been known for several years, ${ }^{2}$ they have found comparatively few synthetic applications. ${ }^{3}$ Recently, we have reported that $\alpha$-iodo- or $\alpha$-bromoalkylboronic esters readily insert zinc dust in THF affording 1,1-bimetallics ${ }^{4}$ of boron and zinc 3 . We have<smiles></smiles>
3: $\mathrm{X}=\mathrm{ZnBr}$ or $\mathrm{ZnI}$<smiles>[R16]C([X])B([O-])OCC</smiles>

2: $\mathrm{X}=\mathrm{Br}, \mathrm{I}$

4: $\mathrm{X}=\mathrm{ZnI}$

5: $X=\mathrm{Cu}(\mathrm{CN}) \mathrm{ZnI}$

6: $X=E$

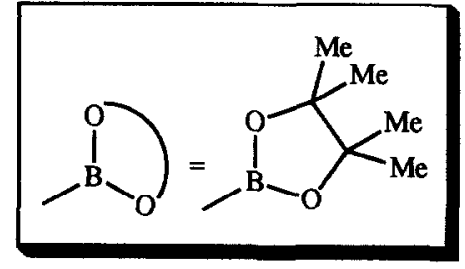

now found that $\alpha$-iodoalkenylboronic esters $2(X=I)$ react with zinc dust in dry $N, N$-dimethylacetamide (DMA) 5 and furnish 1,1 -boron, zinc alkenylbimetallics 4. After a transmetallation to the 1,1-boron, copper 4 bimetallics 5 , these reagents react with a wide range of electrophiles leading to boronic esters 6 which can be oxidized $\left(30 \% \mathrm{H}_{2} \mathrm{O}_{2}\right.$, aq. sat. $\mathrm{NaOAc}$, EtOH:THF $\left.1: 1,25{ }^{\circ} \mathrm{C}, 0.1-1 \mathrm{~h}\right)$ providing various types of polyfunctional ketones 7 (Table I). The $(Z)$ - $\alpha$-iodoalkenylboronic esters 8 were prepared by the hydroboration of 1 -iodoalkynes 9 with $\mathrm{HBBr} 2 \cdot \mathrm{Me} 2 \mathrm{~S}$ (Aldrich) 2,6 in $\mathrm{CH}_{2} \mathrm{Cl}_{2}\left(0^{\circ} \mathrm{C}\right.$ to $40^{\circ} \mathrm{C}$, then $25^{\circ} \mathrm{C}, 2 \mathrm{~h}$ ) followed by the conversion of the intermediate dibromoboronic ester to

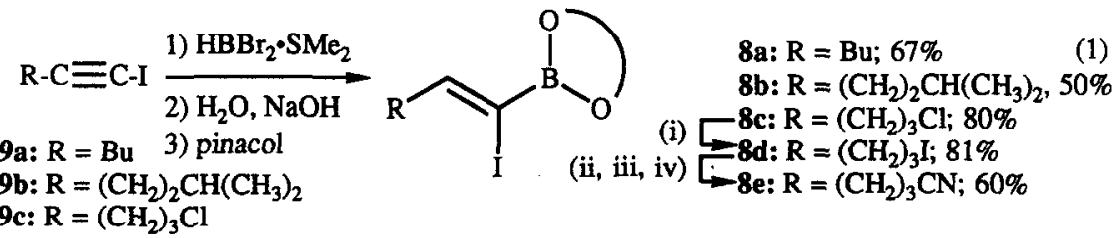

(i) $\mathrm{NaI}, \mathrm{CH}_{3} \mathrm{COC}_{2} \mathrm{H}_{5}, 80^{\circ} \mathrm{C}, 24 \mathrm{~h}$; (ii) $\mathrm{Zn}, \mathrm{THF}, 50^{\circ} \mathrm{C}, 3 \mathrm{~h}$; (iii) $\mathrm{CuCN} \cdot 2 \mathrm{LiCl} ; 0^{\circ} \mathrm{C}, 5 \mathrm{~min}$;

(iv) $\mathrm{p}$ - $\mathrm{TolSO}_{2} \mathrm{CN}\left(0.7\right.$ equiv.), $-60^{\circ} \mathrm{C}$ to $0^{\circ} \mathrm{C}, 30 \mathrm{~min}$.

\footnotetext{
*Present address: Philipps-Universittht Marburg; Fachbereich Chemie; Hans Meerwein Str.; D-3550-Marburg Germany
} 
the corresponding 1-iodoalkenylboronic acid $\left(\mathrm{NaOH}\right.$, ice, AcOEt, $\left.0{ }^{\circ} \mathrm{C}, 3 \mathrm{~min}\right)$ and esterification with pinacol (1.2 equiv.; $\mathrm{MgSO} 4,1: 1$ ether:hexane, $25^{\circ} \mathrm{C}, 1 \mathrm{~h}, 50-80 \%$ overall yield). ${ }^{7}$ The 1-iodoalkenylboronic ester $8 \mathrm{~d}$ was obtained from $8 \mathrm{c}$ by a Finkelstein reaction (NaI (6 equiv.), $\mathrm{CH}_{3} \mathrm{COC}_{2} \mathrm{H}_{5}, 80^{\circ} \mathrm{C}, 24 \mathrm{~h}, 81 \%$ ) and $8 \mathrm{e}$ was prepared from $8 \mathrm{~d}$ by forming chemoselectively the corresponding alkylzinc iodide in THF (no insertion in the alkenyl iodide was observed in this solvent), treatment with $\mathrm{CuCN} \cdot 2 \mathrm{LiCl}^{8}$ and coupling with $\mathrm{p}-\mathrm{TolSO} 2 \mathrm{CN}\left(-60^{\circ} \mathrm{C}\right.$ to $\left.0^{\circ} \mathrm{C}, 30 \mathrm{~min}, 60 \%\right) .9$<smiles>[Z20]=[14C](Br)/C(=C\CCC/C=C/C(=O)OCC)[R]1OCCO1</smiles>

$8 f: 72 \%(2 E, 7 Z$ exclusively $)$
1) $\mathrm{Zn}$, THF, $25^{\circ}$ to $50^{\circ} \mathrm{C}$

2) $\mathrm{CuCN} \cdot 2 \mathrm{LiCl}$

3) $\mathrm{H}-\mathrm{C} \equiv \mathrm{C}-\mathrm{CO}_{2} \mathrm{Et}$ $-50^{\circ}$ to $-40^{\circ} \mathrm{C}, 3 \mathrm{~h}$
1) $\mathrm{Zn}$, THF, 8d $\frac{25^{\circ} \text { to } 50^{\circ} \mathrm{C}}{2)}$

3)

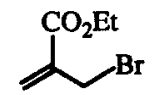<smiles>C=C(CCCC/C=C(\I)B1OCCO1)C(=O)OCC</smiles>

$8 g: 83 \%(E: Z=0: 100)$ (2)

Similarly, the polyfunctional $\alpha$-iodoalkenylboronic esters $8 f$ and $8 \mathrm{~g}$ were obtained in respectively $72 \%$ and $83 \%$ yield as pure $Z$ isomer (eq. 2). The zinc insertion to $\alpha$-iodoalkenylboronic esters does not $\alpha c c u r$ stereoselectively, and the pure (Z)- $\alpha$-iodoalkenylboronic ester $8 \mathrm{a}$ is converted to an $E / Z$ mixture of alkenylzinc iodides $4 \mathrm{a}$ (82:18 as determined by hydrolysis). The iodolysis of $4 \mathrm{a}$ provides the (E)- $\alpha$ iodoalkenylboronic ester $8 \mathrm{a}$ as the major isomer $(E: Z=82: 18)$. After the transmetallation of $4 \mathrm{a}$ to $5 \mathrm{a}$ with $\mathrm{CuCN} \cdot 2 \mathrm{LiCl}$ and addition of Mez $\mathrm{SnCl}\left(0.67\right.$ equiv., $-40^{\circ} \mathrm{C}$ to $\left.25^{\circ} \mathrm{C}, 2 \mathrm{~h}\right)$ a $E / Z$ mixture of the alkenylstannanes $6 \mathrm{~h}(E: Z=82: 18)$; entry 12 of Table $)^{10}$ is obtained. Interestingly, the coupling of $4 \mathrm{a}$ with $(E)-1$-iodooctene ${ }^{11}$ (0.58 equiv.) in the presence of Pd(dba) $2(1 \mathrm{~mol} \%)^{12}$ and PPh3 (4 mol \%) provides only the $(E, E)$-diene $6 \mathrm{a}$ (THF, $20^{\circ} \mathrm{C}$ (exothermic to $35^{\circ} \mathrm{C}$ ), $1 \mathrm{~h} ; 77 \%$; entry 1 ). The reagents 5 are efficient acyl anion equivalents (d 1 . reagents) 13 . Thus, the Michael addition of $5 \mathrm{a}$ to diethyl benzylidenemalonate (entry 2), benzylideneacetone (entry 3 ), cyclohexenone (entry 4 ), ethyl propiolate (entry 5) and ethyl $\alpha$-(bromomethyl)acrylate (entry 7) affords after $\mathrm{H}_{2} \mathrm{O}_{2}$-oxidation 14 a variety of 1,4-dicarbonyl compounds in excellent yields. In the case of the addition of $5 \mathrm{a}$ to nitrostyrene the desired 1,4-adduct was contaminated by the eliminated product 7d. The chromatographed reaction mixture was treated with $\mathrm{DBU}^{15}$ in $\mathrm{CH}_{2} \mathrm{Cl}_{2}\left(25^{\circ} \mathrm{C}, 5 \mathrm{~min}\right.$.) furnishing only $7 \mathrm{~d}$ in $69 \%$ yield (entry 5). The coupling of $5 \mathrm{a}$ or $5 \mathrm{c}$ with 1 -iodohexyne gives after oxidation the corresponding acetylenic ketones $7 \mathrm{~g}(86 \%)$ and $7 \mathrm{n}$ (87\%); see entries 8 and 16. The reaction of $5 \mathrm{a}$ with aldehydes in the presence of $\mathrm{BF}_{3} \cdot \mathrm{OE}_{2}$ provides a new approach to $\alpha$-hydroxyketones (entries $9-11$ ). Polyfunctional 1,1-bimetallics of type 4 or 5 containing a chloride or cyanide functionality react well with electrophiles and lead after oxidation to polyfunctional ketones such as $7 \mathrm{~m}-0$ (entries $15-17$ ).

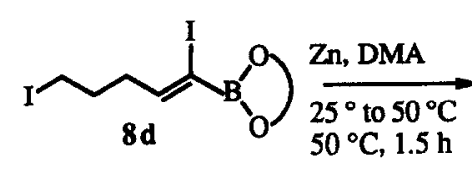

$\overbrace{10}^{\mathrm{ZnI}} \sum_{\mathrm{H}}^{O}{ }_{\mathrm{O}}^{\prime}$

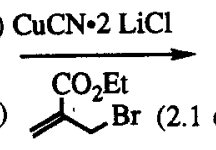

3) $\mathrm{H}_{2} \mathrm{O}_{2}$ oxidation

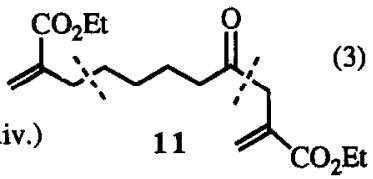

$59 \%$

It was possible to prepare the polymetallic zinc reagent 10 by treating $8 \mathrm{~d}$ with an excess of zinc dust in DMA ( $\left.40^{\circ} \mathrm{C}, 2 \mathrm{~h}\right)$. After transmetallation to the copper compound, addition of ethyl $\alpha$-(bromomethyl)acrylate (2.1 equiv.) and $\mathrm{H}_{2} \mathrm{O}_{2}$ oxidation, the unsaturated ketodiester 11 was isolated in 59\% overall yield (eq. 3). Finally, we have prepared the Diels-Alder adduct 12a from the reaction of $6 \mathrm{a}$ and diethyl acetylenedicarboxylate ( $\left.2 \mathrm{eq}, \mathrm{PhCH}_{3}, 110^{\circ} \mathrm{C}, 3.5 \mathrm{~h}, 67 \%\right)^{16}$ as well as the new 1,2 -diboronic ester $12 \mathrm{~b}$ obtained by the reaction of $8 \mathrm{a}$ $(0.7 \mathrm{eq})$ with $(\mathrm{RO})_{2} \mathrm{BCH}_{2} \mathrm{ZnI}^{4 \mathrm{a}}$ in the presence of $\mathrm{Pd}(\mathrm{dba})_{2}(1 \mathrm{~mol} \%)$ and $\mathrm{PPh}_{3}(4 \mathrm{~mol} \%)\left(\mathrm{THF}, 40^{\circ} \mathrm{C}, 12 \mathrm{~h}\right)$ followed by purification by 
Table I. Products of Type 6 or 7 Obtained by the Reaction of $\alpha$-Metallated Alkenylboronic Esters of Copper or Zinc of Type 4 or 5 with Electrophiles

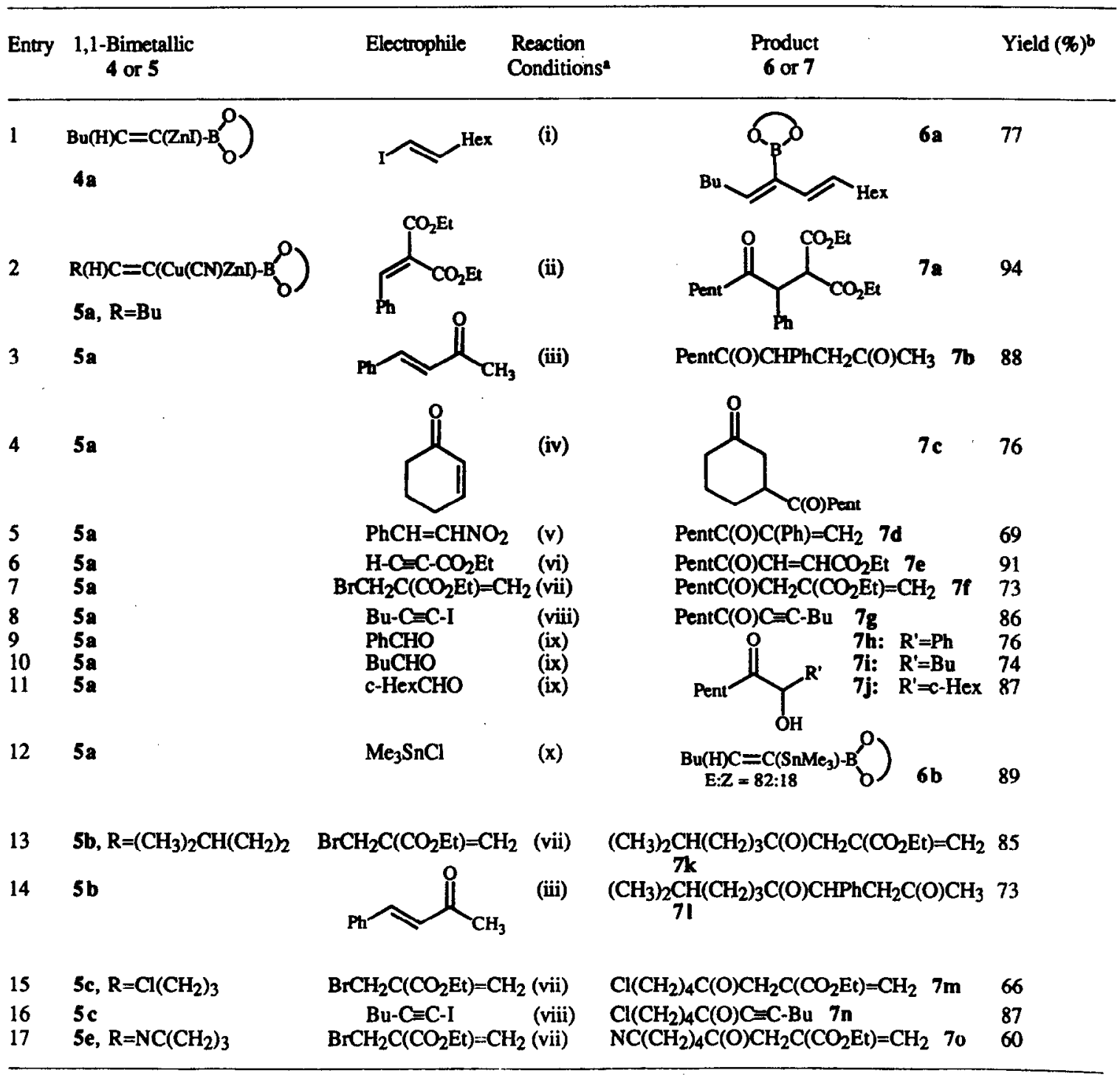

a (i) $\mathrm{Pd}(\mathrm{dba})_{2}\left(1 \mathrm{~mol} \%\right.$ ), PPhy $(4 \mathrm{~mol} \%), 20^{\circ} \mathrm{C}$ to $35^{\circ} \mathrm{C}, 1 \mathrm{~h}$; (ii) $25^{\circ} \mathrm{C}, 10 \mathrm{~h}$, then $\mathrm{H}_{2} \mathrm{O}_{2}$ oxidation; (iii) $\mathrm{Me} 3 \mathrm{SiCl}(2.3$ equiv.), $-78^{\circ} \mathrm{C}$ to $25^{\circ} \mathrm{C}, 12 \mathrm{~h}, \mathrm{H}_{2} \mathrm{O}_{2}$ oxidation; then BunF ( 0.5 equiv.); (iv) $\mathrm{Me} 3 \mathrm{SiCl}$ ( 2.3 equiv.), $-78^{\circ} \mathrm{C}$ to $25^{\circ} \mathrm{C}, 12 \mathrm{~h}$; (v) $-78{ }^{\circ} \mathrm{C}$ to $0^{\circ} \mathrm{C}, 1 \mathrm{~h}, \mathrm{H}_{2} \mathrm{O}_{2}$ oxidation, flash chromatography then $\mathrm{DBU}\left(0.57\right.$ equiv.), $\mathrm{CH}_{2} \mathrm{Cl}_{2}, 25^{\circ} \mathrm{C}$, $10 \mathrm{~min}$.; (vi) $-80^{\circ} \mathrm{C}$ to -40 ${ }^{\circ} \mathrm{C}, 3 \mathrm{~h}$, then $\mathrm{H}_{2} \mathrm{O}_{2}$ oxidation; (vii) $-78^{\circ} \mathrm{C}$ to $0^{\circ} \mathrm{C}, 0.5 \mathrm{~h}$, then $\mathrm{H}_{2} \mathrm{O}_{2}$ oxidation; (viii) $-30^{\circ} \mathrm{C}, 17 \mathrm{~h}$, then $\mathrm{H}_{2} \mathrm{O}_{2}$ oxidation; (ix) $\mathrm{BF}_{3} \cdot \mathrm{OEt}_{2}$ (2.0 equiv.), $-10^{\circ} \mathrm{C}, 15 \mathrm{~h}$, then $\mathrm{H}_{2} \mathrm{O}_{2}$ oxidation; ( $\left.\mathrm{x}\right)-78^{\circ} \mathrm{C}$ to $25^{\circ} \mathrm{C}, 2 \mathrm{~h}$.

b Isolated yields of analytically pure compounds. Satisfactory spectral data (IR, ${ }^{1} \mathrm{H}$ - and ${ }^{13} \mathrm{C}-\mathrm{NMR}$, high-resolution mass spectra) were obtained for all compounds. 
vacuum distillation (bp: $110^{\circ} \mathrm{C}, 0.01 \mathrm{mmHg}$ : $86 \%$ yield). In conclusion, we have shown that 1,1-alkenylbimetallics of boron and zinc (or copper) can be efficient building blocks for the preparation of new polyfunctional boron compounds as well as versatile $\mathrm{d}^{1}$-reagents.<smiles>CCOC(=O)C1=C(C(=O)OCC)[C@@H](Br)C(B2OCCCO2)=C[C@@H]1C</smiles>

$12 \mathrm{a}(67 \%)$<smiles>CCOB(O)C/C(=C/Br)B1OCCCO1</smiles>

$12 b(86 \%)$

\section{Acknowledgments}

We thank the National Science Foundation, the donors of the Petroleum Research Fund, administered by the American Chemical Society and the University of Michigan (Office of the Vice President for Research) for the support of this work. We thank J. Magano for some preliminary experiments.

\section{References and Notes}

1. (a) Matteson, D.S. Acc. Chem. Res. 1988, 21, 294. (b) Matteson, D.S. Tetrahedron 1989, 45, 1859. (c) Matteson, D.S. Chem. Rev. 1989, 89, 1535. (d) Matteson, D.S. Synthesis 1986, 973. (e) Matteson, D.S. in "The Chemistry of the Metal-Carbon Bond: Volume 4", Hartley, F.; Patai, S., Eds. John Wiley and Sons, 1987, 307. (f) Hoffmann, R.W. Angew. Chem., Int. Ed. Engl. 1982, 21,555 .

2. (a) Zweifel, G.; Horng, A.; Plamondon, J.E. J. Am. Chem. Soc. 1974, 96, 316. (b) Brown, H.C.; Bhat, N.G.; Somayaji, V. Organometallics 1983, 2, 1311. (c) Brown, H.C.; Imai, T. Organometallics 1984, 3, 1392. (d) Zweifel, G.; Hahn, G.R.; Shoup, T.M. J. Org. Chem. 1987, 52, 5484.

3. Brown, H.C.; Imai, T.; Bhat, N.G. J. Org. Chem. 1986, 51, 5277.

4. (a) Knochel, P. J. Am. Chem. Soc. 1990, 112, 7431; see also: (b) Matteson, D.S.; Shdo, J.G. J. Org. Chem. 1964, 29, 2742. (c) Zweifel, G.; Arzoumanian, H. Tetrahedron Lett. 1966, 2535. (d) Zweifel, G., Arzoumanian, H. J. Am. Chem. Soc. 1967, 89, 291. (e) Matteson, D.S.; Moody, R.J.; Jesthi, P.K. J. Am. Chem. Soc. 1975, 97, 5608. (f) Matteson, D.S.; Moody, R.J. J. Am. Chem. Soc. 1977, 99, 3196. (g) Kow, R.; Rathke, M.W. J. Am. Chem. Soc. 1973, 95, 2715. (h) Pelter, A.; Buss, D.; Colclough, E. J. Chem. Soc. Chem. Commun. 1987, 297. (i) Pelter, A.; Smith, K.; Elgendy, S.; Rowlands, M. Tetrahedron Lett. 1989, 30, 5643. (j) Pelter, A.; Singaram, S.; Brown, H.C. Tetrahedron Lett. 1983, 24, 1433. (k) Pelter, A.; Singaram, B.; Williams, L.; Wilson, J.W. Tetrahedron Lett. 1983, 24, 623. (1) Pelter, A.; Williams, L.; Wilson, J.W. Tetrahedron Lett. 1983, 24, 627.

5. (a) Tamaru, Y.; Ochiai, H.; Nakamura, T.; Tsubaki, K.; Yoshida, Z. Tetrahedron Lett. 1985, 26, 5559. (b) Majid, T.N.; Knochel, P. Tetrahedron Lett. 1990, 31, 4413.

6. Brown, H.C.; Ravindran, N. Inorg. Chem. 1977, 16, 2938.

7. Tynical nrocedure: Preparation of ( $Z$-pinacol 5-chloro-1-iodo-1-pentenylboronate 8c: A three-necked flask equipped with a thermometer, an addition funnel and a stirring bar was charged under argon with 5-chloro-1-iodo-1-pentyne $9 \mathrm{c}(6.85 \mathrm{~g}, 30 \mathrm{mmol})$ in dry $\mathrm{CH}_{2} \mathrm{Cl}_{2}(20$ $\mathrm{mL}$ ) and cooled to $0^{\circ} \mathrm{C}$. $\mathrm{HBBr}_{2} \cdot \mathrm{SMe}_{2}(8.42 \mathrm{~g}, 36 \mathrm{mmol})$ was then added. The reaction mixture was allowed to reach $25^{\circ} \mathrm{C}$ and an exothermic reaction took place $\left(35^{\circ}-40^{\circ} \mathrm{C}\right)$. The reaction mixture was stirred $2 \mathrm{~h}$ at $25^{\circ} \mathrm{C}$ and poured into a mixture of ice $(200 \mathrm{~g})$ and $\mathrm{NaOH}(3.0 \mathrm{~g}, 75 \mathrm{mmol})$ and stirred for $3 \mathrm{~min}$. Ethyl acetate was added $(100 \mathrm{~mL})$ and the aqueous layer was washed with AcOEt $(2 \times 75$ $\mathrm{mL}$ ). The organic layer was dried over $\mathrm{MgSO}_{4}$, filtered and the solvent was evaporated. The resulting oil was dissolved in ether ( $30 \mathrm{~mL}$ ) and hexane $(10 \mathrm{~mL})$ and stirred for $1 \mathrm{~h}$ with pinacol $(4.25 \mathrm{~g}, 36 \mathrm{mmol})$ and $\mathrm{MgSO}_{4}(7 \mathrm{~g})$. After filtration, the organic layer was worked up as usual. The crude oil was purified by flash chromatography (hexane:ether, 95:5) affording pure $8 \mathrm{c}(8.51 \mathrm{~g}, 80 \%$ yield).

8. Knochel, P.; Yeh, M.C.P.; Berk, S.C.; Talbert, J. J. Org. Chem. 1988, 53, 2390.

9. Westmijze, H.; Vermeer, P. Synthesis 1977, 784.

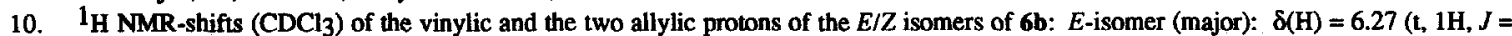
$6 \mathrm{~Hz}) ; \delta\left(\mathrm{CH}_{2}\right)=2.18(\mathrm{q}, 2 \mathrm{H}, J=6 \mathrm{~Hz}) ; \mathrm{Z}$-isomer (minor): $\delta(\mathrm{H})=6.98(\mathrm{t}, 1 \mathrm{H}, J=6 \mathrm{~Hz}) ; \delta\left(\mathrm{CH}_{2}\right)=2.03(\mathrm{q}, 2 \mathrm{H}, J=6 \mathrm{~Hz})$.

11. Zweifel, G.; Steele, R.B. J. Am. Chem. Soc. 1967, 89, 5085.

12. (a) Takahashi, Y.; Ito, T.; Sakai, S.; Ishii, Y., J. Chem. Soc.. Chem. Commun. 1970, 1065. (b) Rettig, M.F.: Maitlis, P.M. Inorg. Synth. 1977, 17, 134.

13. Seebach, D. Angew. Chem. 1979, 91, 259; Angew. Chem., Int. Ed. Engl. 1979, 18, 239.

14. Typical procedure. Preparation of 1-chloro-5-0x0-6-undecyne 7n. A $25 \mathrm{~mL}$, three-necked flask equipped with a magnetic stirring bar, a thermometer and an addition funnel was charged with zinc dust $(900 \mathrm{mg}, 13.5 \mathrm{mmol})$ and flushed with Ar. The zinc dust was activated in dry DMA $(2 \mathrm{~mL})$ with 1,2-dibromoethane $(300 \mathrm{mg})$ and TMSCl $(0.1 \mathrm{~mL})$ as reported previously. 8 The iodide $8 \mathrm{c}(2.0 \mathrm{~g}, 5.4 \mathrm{mmol})$ in dry DMA $(1 \mathrm{~mL})$ was added. An exothermic reaction was observed $\left(25^{\circ}\right.$ to $\left.35^{\circ} \mathrm{C}\right)$ and the reaction mixture was stirred at $40-45^{\circ} \mathrm{C}$ for 0.5-1 h. The completion of the reaction was monitored by GLC analysis of reaction aliquots. Dry THF (10 mL) was added and the excess zinc dust was allowed to settle for $1 \mathrm{~h}$. The clear green solution was transferred via syringe to a THF (5 mL) solution of CuCN (485 mg, $5.4 \mathrm{mmol}$ ) and $\mathrm{LiCl}(459 \mathrm{mg}, 10.8 \mathrm{mmol})$ at $-60^{\circ} \mathrm{C}$. The reaction mixture was allowed to warm to $0{ }^{\circ} \mathrm{C}$ for $5 \mathrm{~min}$. and cooled to $-30^{\circ} \mathrm{C}$ and 1-iodohexyne $(675 \mathrm{mg}, 3.25 \mathrm{mmol})$ was added. After stirring $17 \mathrm{~h}$ at this temperature, the reaction mixhure was worked up as usual (extraction with ether) and the resulting crude oil was dissolved in 1:1 EtOH:THF (20 mL), cooled to $0{ }^{\circ} \mathrm{C}$ and sat. aq. NaOAc (5 mL) and $30 \% \mathrm{H}_{2} \mathrm{O}_{2}(5 \mathrm{~mL})$ was successively added. The reaction mixture is worked up after $10 \mathrm{~min}$. and purified by flash chromatography (ether:hexane, 1:9) affording analytically pure $7 \mathrm{n}(569 \mathrm{mg}, 87 \%$ yield).

15. Seebach, D.; Henning, R.; Mukhopadhyay, T. Chem. Ber. 1982, 115, 1705.

16. Vaultier, M.; Truchet, F.; Carboni, B.; Hoffmann, R.W.; Deune, I. Tetrahedron Lett. 1987, $28,4169$.

(Received in USA 13 March 1992) 